\title{
Alignment between Competitive Strategies and Cost Management: a Study of Small Manufacturing Companies
}

\author{
Maurilio Alves de Melo ${ }^{\dagger}$ \\ Mater Christi School of Science and Technology \\ Rodrigo José Guerra Leone ${ }^{\Omega}$ \\ Potiguar University
}

\begin{abstract}
This article analyzes the alignment between competitive strategies and management of manufacturing costs in small industrial firms for the purpose of obtaining competitive advantages, by means of a descriptive survey with quantitative approach in which the universe was small industrial firms in the transformation segment located in the city of Mossoró, Rio Grande do Norte, Brazil. The main results obtained demonstrate that the integration of competitive strategies with cost management results in advantages, principally for small industrial firms that adopt a stuck-in-the-middle posture with combined priorities for strategic actions by product differentiation and reduction of costs, and that alignment of competitive strategies with cost management is more favorable to small industrial firms that strive for product differentiation and cost leadership simultaneously, or exceptionally focus on differentiation. The results also indicate that competitive advantages emerge both from differentiation and low cost.
\end{abstract}

Keywords: Competitive strategies. Cost management. Competitive advantage.

Received in 28/04/2014; revised in 26/05/2014; accepted in 30/09/2014; divulgued in 01/09/2015

*Author for correspondence:

'. Master's in Business Administration from

${ }^{\Omega} \mathrm{Ph} . \mathrm{D}$. from COPPE/UFRJ

Potiguar University - UNP

Institution: Professor at the Mater Christi School of

Science and Technology

Address: : Rua José Lucas Neto, Nova Betânia,

Mossoró - RN - Brazil

E-mail: maurilio.mello@hotmail.com

Telephone: (84) 9125-5556

Institution: Professor at Potiguar University

Address: Rua Lindolfo José Correa das Neves, João

Pessoa - PB - Brazil

E-mail: r.leone@uol.com.br

Telephone: (83) 8730-2220

Note from the Editor: The article was accepted by Emerson Mainardes. 


\section{INTRODUCTION}

n a market without frontiers characterized by fierce competition among organizations, the adoption of competitive strategies is necessary for the great majority of firms. In this scenario, organizations need to reach decisions with greater strategic focus, because the globalized economy demands more competence and professionalization. This requires constant reformulation of productive processes to make them more competitive or sustainable, in response to the demands of consumers for quality products with accessible exchange value. Knowledge, innovation and technology have become essential elements for companies to survive in a setting of accentuated competition (ZUCKERMAN; ROMOCKI; CHEN, 1997).

The intensification of competition in the business world has required managers to make increasingly complex decisions, making precise risk assessments necessary. The definition of strategies to keep firms competitive requires the adequate use of physical, financial and human resources, to maximize opportunities (OLIVEIRA, 1991).

Besides the mentioned factors, the management of manufacturing costs has gained importance in the process of making administrative decisions. That attention is explained by the fact that organizations have become more complex, requiring the use of new cost management strategies to improve organizational performance and to favor the development of products with competitive exchange value.

Small manufacturing firms, responsible for turning raw materials into final or finished products, face a particularly competitive environment because of economic growth in recent years. Liberal economic policies have contributed to this competitive environment. These policies were decisive for economic opening and deregulation of the market, leading to greater pressure from imported products and forcing firms to increase productivity, improve quality and develop products with increasingly accessible exchange value.

To face competitive forces, according to Porter (1995) industrial firms should adopt one of three generic competitive strategies: cost leadership, differentiation or focus. Some firms base their competitive strategies on control, maintenance and monitoring of production costs, to maximize earnings by reducing costs, or by adjusting to rules of the market. Others strive, through systematic procedures, to develop differentiated products in relation to those made by rivals, in terms of quality, technology and/or other attributes. Still other companies focus on a specific segment or type of customer (PORTER, 1985). 
Easier access to information and the penetration of new companies in the market have worked to expand the horizons of the business strategies of small enterprises as well as large corporations. Besides this, cost management has gained attention in administrative decisions because of the need for industrial companies to develop more competitive products.

Besides the possible strategies proposed by Porter, the choice of an efficient costcontrol system and an adequate costing method can be a way for firms to face competitive forces, especially by offering high-quality products with accessible exchange value.

Both academic works and practical business experience show that achieving a competitive edge results from effective cost management and well-developed strategies. In this line, our aim here is to answer the following question: What is the effect of alignment between competitive strategies and cost management to obtain competitive advantages by small manufacturing firms?

\section{ALIGNMENT OF COMPETITIVE STRATEGIES AND COST MANAGEMENT}

This study draws inspiration from the competitive strategies proposed by Porter (1985), according to whom companies need to position themselves adequately to achieve advantages in relation to their rivals, by means of cost leadership, differentiation or focus.

The cost leadership strategy assumes that a competitive advantage is the result of production strategies concentrated on having the lowest manufacturing cost, to enable the firm to offer prices that are compatible or lower than those of competitions. The differentiation strategy, in turn, can be summarized as offering products with special or singular attributes in relation to those of competitors. Finally, the focus strategy involves concentrating commercial efforts on a determined group of buyers, product segment or geographic market. Therefore, the manufacturing priorities can favor one of the mentioned strategies in some way.

An example of this is the winning production criteria developed by Hill (1997) - price, product quality and fast and reliable delivery - in which price is related to low manufacturing cost, product quality depends on the dimensions, specifications and reliability, and fast and reliable delivery is required by the need for competency to meet increasing demand.

The perception of strategic alignment adopted here refers to the orientation of cost management to the firm's strategic priorities, or the conformation of cost management practices and their structure with the strategic objectives defined by the organization. There is a broad consensus that strategic cost management concentrates the analysis of manufacturing 
costs in a broader environment, considering strategic elements as sources of competitive advantages.

For Shank and Govindarajan (1997), strategic cost management (SCM) results from the combination of three underlying themes about strategic management found in the literature:

(I) value chain analysis, a set of activities to create value ranging from choice of the source of raw materials to delivery of the product to consumers; (II) strategic positioning analysis, involving the choice of how the firm will compete, whether by lower costs (cost leadership) or better products (differentiation); and (III) cost driver analysis, involving complex and interrelated factors that determine the firm's costs.

The interface of competitive strategies and cost management is possible when costs are treated as a strategic element of the company, since certain strategic objectives can only be reached through cost management practices that enable the company to offer products with competitive exchange value or singular attributes in relation to those of rivals. Therefore, for cost management to acquire strategic status, it must be based on the concept that costs, in most cases, are consequences of previous investment decisions, and it should provide information to support the formulation, development and generation of new strategies (SOUZA; CLEMENTE, 1998).

As observed, the success or competitive capability of a company does not only involve its productive competence. It also includes the way this skill is aligned with the firm's strategies. The information on costs is used to prepare better strategies, contributing to aggregate value to customers at a cost that is equal to or lower than that of competitors, resulting in a competitive advantage for the organization (HANSEN; MOWEN, 2001).

Good alignment between business strategies and cost management is perceived to the extent that accounting information is adequate to the firm's strategic needs. Delayed and inopportune operational information impairs the performance of accounting information, which should facilitate the development and implementation of management strategies (SHANK; GOVINDARAJAN, 1997).

Several studies have been published in recent years regarding the relationship between business strategies and cost management in the industrial and service sectors. Their results suggest the existence of integration between cost management and certain business strategies.

Silva (2003) investigated the competitive strategies of furniture makers in the city of Votuporanga (São Paulo state), and from their identification verified the existence of 
integration of competitive strategies with production strategies. The results identified various factors that can impede alignment of low-cost competitive strategy with the competitive cost priority. Nevertheless, the author found that some production decisions tend to influence reduction of manufacturing costs, but that these decisions were taken with a short-term perspective, not generating competitive advantages from low cost over the medium and long range.

Fonseca (2007) sought to understand the factors that enable alignment between corporate strategies and cost management to achieve efficient operational costs. For this purpose, he carried out a study involving comparative content analysis of three electricity companies. The results revealed the existence of very specific alignment processes. However, the findings also indicated the existence of some similar characteristics in the integration process, leading to the proposal of a basic model for cost management as the main contribution of the study.

Frega, Lemos and Souza (2007) carried out a case study of a company in the brick and ceramic segment in southern Brazil. The aim was to discuss the dynamic of the alignment of competitive strategies, investment decisions and cost management systems for the generation of a sustainable competitive advantage. The study revealed that for the firm to attain better competitive advantages, it should replace the use of a traditional costing method, such as absorption, with the direct costing method allied with time-driven ABC. They found the existence of a dynamic alignment between strategy and cost structure, and that in the majority of cases, the level of relevant costs results from previous investment decisions.

With the objective of understanding how competitive and cost strategies interact with the product development process, Tondolo (2010) carried out a multiple case study of three companies in the mountain region of the state of Rio Grande do Sul. The results demonstrated that the activities involving product conception received considerable attention in the firms studied, since the decisions made in this phase influence the success of the product in the market. The firms had different forms of integration, in which costs were directly connected to competitive strategies in the sense of developing competitive products.

Finally, Almeida, Machado and Panhoca (2012) performed a study of construction companies in the Brazilian state of Paraná, focusing on the cost management practices following the typology of Porter. The results indicated that firms with differentiation strategies tend to attribute more importance to cost management strategies. The conclusion diverged from that of Chenhall (2003), to the extent that firms that adopt low cost strategies 
tend to use managerial controls focused on cost control and rigid budgetary controls when compared to firms that adopt differentiation strategies.

\section{METHODOLOGY}

With respect to objectives, this is a descriptive study in the sense that we observed, registered, analyzed and correlated facts and phenomena without manipulation, to find evidence of the occurrence of a phenomenon and its integration with others, as well as its nature and characteristics (BERVIAN; CERVO, 1996). The descriptive method served to depict the particularities of the firms studied and indicate the competitive strategies utilized and the cost management practices adopted. Therefore, the model is a reference to the form of the strategic and cost management of the small companies investigated, not a specification.

In relation to the approach to the problem, this study is quantitative in nature. Quantitative treatment is justified by the need to use quantification and statistical instruments, both for collection and treatment of the data (BEUREN, 2006). Besides this, the quantitative approach is often used in descriptive studies that seek to identify the relation between variables and the causality between phenomena (GIL, 2008). Therefore, we applied this approach to measure the degree of relationship of the strategic variables, according to the model of Porter (1985), and cost management, to evidence how much this interaction can contribute to attaining a competitive advantage.

Regarding procedures, this is a field study, namely an empirical investigation conducted by means of a survey of managers of small manufacturing companies in the city of Mossoró, Rio Grande do Norte.

The universe of firms studied consisted of small manufacturing firms in the city of Mossoró, identified from the database of the Rio Grande do Norte State Federation of Industries (FIERN). Among them, there were 52 firms classified quantitatively as small, considering the number of employees, according to the criterion established by the Brazilian Service to Support Micro and Small Businesses (SEBRAE). Of the 52 companies in the FIERN database, 49 were engaged in manufacturing activities, one was only a service provider and two were inactive.

The data were collected by sending a questionnaire to a key director or manager of each of these 49 companies, of which 45 were answered. The option to target directors and managers was due to the need for the respondents to know the details of the strategic 
decisions and the manufacturing cost management policies. The questionnaire contained structured questions with scoring of responses using a Likert scale of five points.

To elicit information related to the competitive strategies of the firms studied, we formulated questions based on those used by Bacurau (2006), who sought to identify the generic competitive strategies according to the framework of Porter and their relation with performance of retail clothing and shoe stores in the five largest shopping centers in Natal, capital of Rio Grande do Norte. To obtain data related to cost management, we adapted the questions formulated by Eidt (2006), who studied cost management in furniture makers in the western part of the state of Santa Catarina.

In relation to evaluation of competitive advantages, we formulated questions using as a reference the study conducted by Gulini (2005). He evaluated the relationship of organizational environment, strategic behavior and performance perceived by managers of internet service providers in the state of Santa Catarina. We also formulated questions to shed light on the firms' competitive advantages according to the three categories proposed by Porter (1985): cost leadership, product differentiation and focus.

The raw data were tabulated and analyzed, and are presented here in descriptive form. In the case of unanswered questions, the scores were assigned according to the average of the variable. We used statistical techniques, such as calculation of the mean and application of cluster analysis and discriminant analysis to clarify the relations of interest.

To discern the strategic positioning of the firms studied, we applied a non-hierarchical grouping technique called $k$-means cluster analysis. This technique consists of allocating each observation to the cluster with the nearest mean, or shortest distance to the centroid, based on original numerical or binary data, where the number of groups of observations is predefined. Therefore, the model served to group the firms according to the mentioned strategies, i.e., cost leadership, differentiation and focus. The mean was used as a parameter to measure and indicate the possible strategies used by the companies. The cutoff point was 3.50, i.e., an average greater than 3.50 meant adoption of the strategy and an average below 3.50 indicated its absence.

We also calculated the averages (arithmetic means) to measure the firms' cost management practices. More specifically, we calculated the means to measure the level of costs and to identify the form of cost accrual, i.e., by order of production or continuous process, as well as to evidence the costing method used to value inventories. 
We also applied the descriptive method to gauge the existence of competitive advantage of the firms, by means of frequency distributions. This involved calculating the average to identify whether each firm had an advantage in cost leadership or differentiation. Each firm received score from 1 to 5 , to indicate the strength of the competitive advantage in relation to competitors. Again, the cutoff value was 3.50, so those with average above this were deemed to have a competitive advantage while scores below this indicated absence of superiority.

Finally, we applied discriminant analysis to assess the interplay of competitive strategies, cost management and competitive advantage, since this is a statistical technique that allows, by means of qualitative (non-metric) variables, estimating the values of the dependent variables, defined by the researcher, in relation to the independent variables (CORRAR, PAULO, FILHO, 2009). This method contributed to classify and estimate whether the firms attained competitive advantages by reason of strategic integration and managing manufacturing costs.

\section{ANALYSIS OF THE RESULTS}

\subsection{PROFILE OF THE RESPONDENTS AND FIRMS}

This section describes the profile of the respondents and the main characteristics of the firms. In the case of the respondents, we asked about the position held, gender, age range, schooling level and time with the company. With respect to the firms, we ascertained the period of existence, size and segment of activity.

We received 45 questionnaires, of which we used 44. The respondents were all directors or managers of manufacturing firms in the city of Mossoró, Rio Grande do Norte, enrolled with the RN State Federation of Industries (FIERN). Of the respondents, 70\% [ $n=31]$ held the position of manager, $72 \%[n=32]$ were male, $52 \%[n=23]$ had college degrees, of whom $22 \%[n=10]$ had postgraduate degrees. The age breakdown was $27 \%[n=12]$ up to 30 years old, $50 \%[n=22]$ between 31 and 50 years and $23 \%[n=10]$ older than 50 . Finally, $56 \%[n=25]$ of the respondents had been with the same firm for more than five years.

We gathered these data to analyze the profile of the respondents regarding position held, sex, age, time with the company, and particularly level of schooling. The data showed that most of the respondents were classified as managers and most were men. The respondents on the whole had a good level of schooling, since 52\% $[n=23]$ had college degrees and $18 \% \quad[n$ $=8$ ] were studying part time to obtain degrees. This helped the firms have good strategic and cost management. 
The majority of the interviewees were 50 years old or younger $(77 \%[n=34])$. Besides this, the length of service was good, with $56 \%[n=25]$ of the respondents having more than five years with the firm, meaning good familiarity with the administrative decisions and manufacturing processes, contributing to the reliability of the results.

Regarding the firms, 93\% $[n=41]$ were older than five years. By design, all the firms were classified as small businesses according to the criterion established by SEBRAE, which considers the number of employees. In the case of the industrial sector, the range is 20 to 99 employees (with smaller firms being classified as micro-enterprises and larger ones as either midsize or big companies). The companies were active in various manufacturing segments, of which the standouts were food products, with $25 \%[n=11]$, non-metal mineral products, with $13 \%[n=6]$, and metal products, with $11 \%[n=5]$.

\subsection{STRATEGIC POSITIONING}

To ascertain the firms' strategic positioning, we applied the non-hierarchical grouping technique called $k$-means cluster analysis. For this purpose, we formed four clusters with the data collected, quantified by frequency. The objective was to group the firms with similar strategic characteristics, as shown in Table 1.

Table 1 - Competitive Strategies

\begin{tabular}{|c|c|c|c|c|c|c|}
\hline \multicolumn{2}{|c|}{ Characteristics of the cluster } & \multicolumn{3}{|c|}{ Competitive strategies } & \multirow[t]{2}{*}{$\begin{array}{c}\text { Total } \\
\text { number } \\
\text { of firms }\end{array}$} & \multirow[b]{2}{*}{$\%$} \\
\hline & & Differentiation & $\begin{array}{c}\text { Cost } \\
\text { leadership }\end{array}$ & Focus & & \\
\hline Cluster 1 & $\begin{array}{l}\text { Strongly stuck in } \\
\text { the middle }\end{array}$ & 4.51 & 3.93 & 2.64 & 15 & $34 \%$ \\
\hline Cluster 2 & Differentiation & 3.51 & 3.35 & 3.04 & 9 & $21 \%$ \\
\hline Cluster 3 & $\begin{array}{l}\text { Weakly stuck in the } \\
\text { middle }\end{array}$ & 3.68 & 3.60 & 1.77 & 16 & $36 \%$ \\
\hline Cluster 4 & Cost leadership & 2.21 & 4.00 & 2.95 & 4 & $9 \%$ \\
\hline
\end{tabular}

Source: Survey data.

The results allow indicating the generic competitive strategies of the firms according to the categories proposed by Porter (1985). The mean of the clusters served as a parameter to define the strategic positioning as fitting better or worse in the strategic models suggested by the author. Therefore, we considered an average $>3.5$ to confirm the option for the particular model, with and average $\leq 3.5$ indicating the opposite.

Cluster 1 is composed of 15 firms with leadership strategy characteristics involving product differentiation and low production costs, representing $34 \%$ of the surveyed firms. The 
data for this group show that the firms adopt a strategic positioning focused both on fabrication of differentiated products, i.e., with singular characteristics and added value for customers, along with reduction of costs. In other words, these firms do not follow a single strategy, as urged by Porter (1985). However, according to Miller and Dess (1993), it is common for companies to use more than one generic strategy to remain competitive, adopting a "stuck-in-the-middle" concept, as also mentioned by Hill (1988).

Cluster 2 is composed of nine firms (21\% of the sample) that follow a product differentiation strategy. Despite the indication of this positioning, there is a relative balance among the three possible generic strategies in this group, since cost leadership presented an average of 3.35 and focus received 3.04. The set is composed of firms with narrow focus, that offer singular products with a restricted strategic target compared to competitors. Therefore, in this strategic positioning model, the premise is to serve a specific niche with products having superior quality.

Cluster 3 is the most representative group, accounting for $36 \%[n=16]$ of the firms. This group has particularities similar to cluster 1, with strategic positioning having a broad focus on fabrication of differentiated products with low production cost. Like the previous group, in this cluster the firms have stuck-in-the-middle characteristics, without being classified as leaders in any of the possible strategies. They have means lower than those for cluster 1, paying only moderate attention to manufacture of differentiated products and reduction of production costs. Again, these firms do not have a defined strategy, and can be classified according to the framework of Porter (1985) as weakly stuck in the middle, unable to attain competitive advantage over their rivals.

Finally, cluster 4 is composed of firms with competitive strategies based on cost leadership, with focus on cutting production costs without giving high priority to product differentiation. This group is the smallest in the survey, representing $9 \%[n=4]$ of the firms. In this form of positioning, the company seeks rigorous reduction of costs, high market share and convenient access to raw materials, among other advantageous positions. It is a model that, if well disseminated within the firm, can lead to returns above the average for the sector, because the company can offer products similar to those of rivals at reasonably low costs. For this purpose, actions are necessary that help attract customers that are flexible to lower prices, in this case the target public (PORTER, 1995).

In light of this analysis, it can be seen that a large percentage of the firms adopt a stuckin-the-middle position, with greater or lesser degree of priority on differentiation and cost 
leadership strategies. The firms in cluster 1, although not having a single strategy, as urged by Porter (1985), concentrate greater efforts on differentiation and low cost strategies compared to those in cluster 3 . The data reveal equilibrium between the firms that take a middle-of-theroad approach with higher strategic priority (cluster 1), 34\% of the sample [ $n=15]$, and those that are take that approach with weaker priority (cluster 3), composed of $36 \%$ [ $n=16]$.

The great majority of the firms studied therefore have a stuck-in-the-middle position. This finding is in line with that of Bacurau (2006), studying small retail shops, in which $48.84 \%$ of the firms studied did not have a single generic competitive strategy. However, a study conducted by Dess and Davis (1984) among American companies in the paint industry found that companies with single strategies showed better results than those with mixed strategies. That result corroborates the opinion of Porter (1985) that a company having a stuck-in-the-middle strategy will only attain superior performance if it is favored by the structure of its sector or if the main competitors also adopt that mixed strategy.

\subsection{COST MANAGEMENT PRACTICES}

In this section we analyze the level of cost management practiced by the firms in our sample. We first tried to verify whether the firms record their manufacturing costs separately in their accounts. According to the data, 91\% $[n=40]$ of the firms adopt cost accounting practices to measure the manufacturing costs, $7 \%[n=3]$ do not do this, and $2 \%[n=1]$ are indifferent to the employment of this technique to the productive process. Therefore, the results indicate that the great majority of firms apply accounting techniques as a tool to evaluate their production costs.

After this initial analysis, we sought to identify the system of cost accrual utilized by the firms for keeping track of the costs of their activities, products or both. The result reveal that $57 \%[n=25]$ of the firms surveyed accrue manufacturing costs both by order of production or purchase order and by the continuous process. In the literature, the general interpretation is that techniques of cost accrual are distinct, a situation that can be explained, according to Martins (2003), by the exaggerated use of the idea of costs for production by order and for continuous production. However, in reality the differences are small and it is not impossible to use two accrual techniques simultaneously, applied to a customized product or even a massproduced one.

In relation to the cost distribution method, the results indicate that a substantial portion of the firms use cost appropriation practices involving all three of the methods mentioned in the questionnaire: absorption, variable and $\mathrm{ABC}$, for a total of $23 \%[n=10]$. We also found 
that costing activities by the absorption model are practiced as the norm by $80 \%[n=35]$ of the firms, and that this model is used exceptionally in specific situations by $34 \%$ [ $n=15]$ of the firms.

This costing model is propitious to companies that only evaluate inventories, without concern for management information. A study conducted by EIDT (2006) among six furniture makers in the western part of Santa Catarina found that four of them used absorption costing exceptionally to value their inventories.

The second leading method among the companies was activity-based costing. This method can bring important management benefits, since the distribution of costs based on activities reduces the subjectivity of apportioning indirect costs, making the information on manufacturing costs more precise, possibly enhancing competitiveness.

A case study conducted by Frega, Lemos and Souza (2007) of a brick and ceramic company identified this gain, finding that the company had migrated from absorption costing to direct costing combined with $\mathrm{ABC}$ for the purpose of improving its competitiveness. This enabled the company to move toward the concept of lean production. The data in this study point to the absorption and activity-based costing methods as the main tools used to value inventories and support management decisions by the small firms in the sectors analyzed.

Besides identifying the costing systems and methods used, we also observed other practices for measuring the cost management of these firms, such as adoption of budgets in the productive process, criteria for identification of manufacturing costs and formation of selling price (based on costs, competitors or markup).

According to the data collected, $86 \%[n=38]$ of the firms adopt budgeting in the manufacturing process. The use of this technique is important for administrative decisions, because it guides managers regarding the introduction or discontinuation of products, pricing decisions and the option to buy or produce intermediate products, besides supplying data for comparison against values defined in advance (MARTINS, 2003). We also found that $43 \%[n$ $=19$ ] of the firms employ segmentation of activities, departments, cost and product centers as a way to facilitate measurement of production costs.

Finally, we identified the parameters used by the firms to price their products. In this respect, $37 \%[n=17]$ of the companies set the selling price by considering the manufacturing cost, prices charged by rivals and markup, while $32 \%[n=14]$ prioritize costs and markup, $11 \%[n=5]$ focus on fabrication costs and $7 \%[n=3]$ pay heed to manufacturing costs and 
competitors' prices. So, the great majority of the firms use production cost information as a parameter in forming their selling prices, since only $7 \%[n=3]$ of the respondents stated their firms did not pay attention to manufacturing costs in pricing their products. The data thus suggest that the firms analyzed have good costing practices, which can enhance their competitiveness.

\subsection{RELATIONSHIP OF COMPETITIVE STRATEGIES, COST MANAGEMENT AND COMPETITIVE ADVANTAGE}

In this section we describe the competitive strategies and cost management practices of the firms in relation to achieving competitive advantage. The results of discriminant analysis indicated that $75 \%[n=33]$ of the firms that were classified based on the average adopted for this study as having a competitive advantage or not have the same position when correlating the variables of the competitive strategies and cost management.

Therefore, of the 31 firms judged to have an advantage based on the average, the prediction suggested that 23 also attain excellence due to the integration of the mentioned variables. Conversely, of the 13 without a competitive advantage based on the average, the prediction indicated that only 3 reach supremacy, even though having a lower average than that adopted as the cutoff.

The percentage of coincidences between the original value (average) and predicted value was very good, because the prediction suggested that only 11 firms received different classifications than what was defined by the mean. Therefore, of the 31 companies considered as having a competitive advantage based on the average, the prediction indicated that $74 \% \quad[n$ $=23]$ also reach excellence because of the relationship of competitive strategies and manufacturing cost management.

Regarding the firms judged not to have a competitive advantage based on the average, the prediction identified only three as reaching superiority, even though having means lower than the cutoff adopted. In general, the companies judged as attaining excellence were divided in various fields of activities within the manufacturing segment.

The results indicate that $83 \%[n=19]$ of the firms have a stuck-in-the-middle competitive position, of which $73 \%[n=14]$ strongly prioritize product differentiation and cost leadership strategies. The excellent results attained by these companies are coherent with the competitive position adopted, since the advantage found was due to the offer of products with differentiated characteristics and competitive prices, or at least prices acceptable by the market in terms of exchange value. 
To maintain the mentioned competitive positions, we found that some strategic actions are prioritized. Among these, the standouts are: (I) bargaining with suppliers to obtain better prices and payment conditions; (II) production of large quantities to reduce unit costs; (III) fabrication of products with differentiated characteristics compared to those made by rivals; (IV) adoption of criteria to attract customers to differentiated products; (V) concern with the qualification of employees, leading the firms to invest more in training than their competitors; (VI) customer response programs, and (VII) innovation and launch of new products more than competitors.

Although the strategic activities identified in this study are more aimed at product differentiation, we also found that firms with competitive advantage take measures to reduce production costs, such as negotiating with suppliers for lower prices and better payment conditions, as well as large production runs to reduce unit costs, suggesting a middle-of-theroad position.

The results obtained by this survey conflict with the position of Porter (1985), according to whom a company should focus on only one of the possible generic strategies (cost leadership, differentiation or focus), so that those that are stuck in the middle tend not to have successful strategies, able to result in a competitive advantage.

The conception of Porter has been questioned by several authors. For example, Miller (1992) cited Caterpillar Inc. as an example of a company with excessive focus on differentiation, by making products with high quality and durability but not paying sufficient attention to efficiency and economies of scale, leaving it vulnerable to Japanese competitors.

Other examples are the studies of Kim and Lim (1988) and Bacurau (2006), who have provided evidence that the stuck-in-the-middle position can be a good alternative for firms to attain competitiveness, including small ones. Porter (1985) himself stated that this fencesitting strategy can result in advantages, but established some uncommon criteria, mainly for small companies, such as a situation where a firm has a key patent that gives it an edge, or when the main competitors also adopt the same position, or when the structure of the industry favors a mixed position.

With respect to manufacturing costs, we found that firms that have a competitive advantage have a good level of cost management practices, because $83 \%$ [ $n=19]$ obtained an average greater than 3.50, regardless of the strategic position adopted, be it differentiation or a mixed strategy. We also found that $96 \%[n=22]$ of the firms account for their production 
costs. Booking of activities that cause changes in net worth because of the manufacturing process is important not only for firms to coherently appraise their inventories, but also to reach well-informed decisions.

In relation to the system of cost accrual used by the firms having a competitive advantage, we identified a substantial percentage that use a system by chronological order of production or of receiving purchase orders, simultaneously with a continuous process. The adoption of the referred models in integrated form is possible to the extent that firms also employ ongoing measures to optimize production and at the same time carry out actions that favor cost accrual individually for certain cost categories, such as products.

Regarding the cost appropriation methods, the results indicate that the firms analyzed prioritize distribution of costs through simultaneous use of absorption, variable and activitybased costing methods. The adoption of those mixed costing models is possible since they have distinct purposes.

Besides the factors mentioned, we also found an important number of companies that adopt only one cost appropriation method, with the standout being absorption costing, used exclusively by $30 \%[n=7]$ of the firms judged to have a competitive advantage by the criteria applied. This method is typical of firms that only prioritize satisfaction of tax and commercial demands, limiting themselves to certain formalities, mainly regarding valuation of inventories.

The cost management practices evidenced in the small industrial firms studied are ratified since we identified an important number of companies that use manufacturing cost information as a parameter to establish the selling price of their products. The results indicate the presence of cost information as a pricing criterion in $96 \%$ [ $n=22]$ of the firms having a competitive advantage.

Besides production costs, we found that $70 \%[n=16]$ of the firms use the markup technique, while 39\% [ $n=9$ ] consider rivals' prices. According to Santos (1988), the markup technique is a simple way of pricing, but the model assumes that the market is willing to pay the price defined by the company, which can generate important distortions, mainly due to consumers' reluctance and the prices offered by competitors.

We found that the firms having competitive advantage prioritize manufacturing cost information in pricing decisions while paying little attention to the prices charged by 
competitors. This can be explained by a strategic positioning more oriented toward product differentiation.

It is natural for the emphasis on costs to be more common among firms that adopt a cost leadership strategic position. However, we found that the firms with differentiation position also prioritize manufacturing cost management. A study carried out by Almeida, Machado and Panhoca (2012) among construction companies reached a similar result, by identifying that the firms that gave importance to cost management practices also adopted differentiation.

Therefore, cost management is an important tool to sustain the competitive position of the companies analyzed, whether this position is differentiation or a mixed strategy, and this relationship has resulted in superiority for the industrial firms analyzed in this study.

\section{FINAL CONSIDERATIONS}

The chief objective of this study was to analyze the alignment of competitive strategies, cost management and competitive advantage in small manufacturing firms. Initially we investigated the strategic positioning of the firms studied. Then we estimated the firms' level of manufacturing cost management as well as whether they have a competitive advantage based on differentiation, cost leadership of both. Among the findings, the results indicate that most of the firms that focus on differentiation and cost leadership simultaneously have an advantage in their strategic position.

The superiority of these firms could be perceived in the main strategic actions adopted, with the following standing out: (i) bargaining with suppliers to obtain better prices and payment conditions; (ii) production of large quantities to reduce unit costs; (iii) fabrication of products with differentiated characteristics compared to those made by rivals; (iv) adoption of criteria to attract customers to differentiated products; (v) concern with the qualification of employees, leading the firms to invest more in training than their competitors; (vi) customer response programs, and (vii) innovation and launch of new products more than competitors.

The findings on the cost management of the firms having competitive advantage present evidence that manufacturing firms with strategic positioning focused on product differentiation also prioritize production cost management. The level of cost management of these firms was revealed by the high average presence of the cost management practices presented, among which cost accounting using budgets, costing systems and product pricing stand out. 
In their costing practices, the firms tended to use more than one method for distribution of costs, which indicates managers' concern for following legislation, by means of adoption of absorption costing and use of management information, mainly the use of variable and activity-based costing.

The manufacturing cost information serves as the starting point for pricing decisions of the firms analyzed, followed by markup and competitors' prices. We stress that production cost information is not solely used to price products, only serving as one parameter for this purpose, since other factors are used, such as return margin according to the markup technique and consideration of the prices charged by the main competitors.

The correlation of the competitive strategies with cost management allowed identification, by means of discriminant analysis, of the firms that achieve advantage by the referred integration. The strategic alignment was perceived in function of the strategic actions evidenced, oriented to product differentiation and cost leadership.

The referred competitive strategies are reinforced by the level of costs verified, suggesting an important contribution for these firms to offer high-quality products at competitive prices. Therefore, the perception of competitive advantage is evidenced to the extent the firms maintain a good level of cost management and strategy focused on differentiated products at attractive prices.

\section{REFERENCES}

ALMEIDA, L. B; MACHADO, E. A; PANHOCA, L. Práticas de gestão de custos e perspectivas estratégicas: um estudo na indústria da construção do estado do Paraná. Revista brasileira de gestão de negócios, São Paulo, v. 14, n. 44, p. 353-368, jul./set. 2012.

BACURAU, F. B. F. Estratégias competitivas genéricas nas empresas comerciais varejistas de shopping centers: um estudo a partir do modelo de Porter. 2006. $138 \mathrm{f}$. Dissertação (Mestrado em Administração) - Universidade Federal do Rio Grande do Norte. Natal, Natal (RN), 2006.

BERVIAN, P. A.; CERVO, A. L. Metodologia científica. 4. ed. São Paulo: Makron Books, 1996.

BEUREN, I. M. et al. Como elaborar trabalhos monográficos em contabilidade: teoria e prática. 3. ed. São Paulo: Atlas, 2006.

CORRAR, L. J.; PAULO, E.; DIAS FILHO, J. M. Análise multivariada para os cursos de administração, ciências contábeis e economia. São Paulo: Atlas, 2009. 
CHENHALL, R. H. Management control systems design within its organizational context: findings from contingency-based research and directions for the future. Accounting, Organizations and Society, Oxford, v. 28, n. 2-3, p. 127-168, fev./abr. 2003.

DESS, G. G.; DAVIS, P. S. P. Generic strategies as determinants of strategic group membership and organizational performance. Academy of Management Journal, v. 27, n. 3, p. 467-488, 1984.

EIDT, J. Gestão de custos em indústrias do setor moveleiro estabelecidas na região do oeste do estado de Santa Catarina: um estudo multicasos. 2006. 234 f. Dissertação (Mestrado em Ciências Contábeis) - Centro de Ciências Sociais Aplicadas da Universidade Regional de Blumenau, Blumenau (SC), 2006.

FIERN. Federação das Indústrias do Estado do Rio Grande do Norte. Disponível em: $<$ http://cadindustrial.fiern.org.br/>. Acesso em: 07 fev. 2013.

FONSECA, J. N. Estratégias corporativas e gestão de custos: um alinhamento necessário para atingir custos operacionais eficientes. 2007. 147 f. Dissertação (Mestrado em Administração) - Centro de Ciências Sociais Aplicadas, Pontifícia Universidade Católica do Paraná, Curitiba (PR), 2007.

FREGA J. R.; LEMOS I. S.; SOUZA A. C. A dinâmica do alinhamento entre as estratégias competitivas e a gestão de custos. Um estudo de caso. In: CONGRESSO BRASILEIRO DE CUSTOS, 14., 2007, João Pessoa (PB). Anais... João Pessoa: ABC, 2007.

GIL, A. C. Métodos e técnicas de pesquisa social. São Paulo: Atlas, 2008.

GULINI, P. L. Ambiente organizacional, comportamento estratégico e desempenho empresarial: um estudo no setor de provedores de internet de Santa Catarina. 2005. $160 \mathrm{f}$. Dissertação (Mestrado em Administração) - Centro de Administração da Universidade do Vale do Itajaí. Biguaçu (SC), 2005.

HANSEN, D. R., MOWEN, M. M. Gestão de custos: contabilidade e controle. São Paulo: Pioneira Tomson Learning, 2001.

HILL, C.W. L. Differentiation versus low cost or differentiation and low cost: a contingency framework. Academy of Management Review, v. 13, p. 401-412, 1988.

HILL, T. J. Manufacturing strategy: keeping it relevant by adressing the needs of the market. Integrated Manufacturing Systems, Bradford, v.8/5, p.257-264, 1997.

KIM, L.; LIM, Y. Environment, generic strategies and performance in a rapidly developing country: a taxonomic approach. Academy of Management Journal, v. 31, n. 4, p. 802-827, 1988.

MARTINS, E. Contabilidade de custos. 9. ed. São Paulo: Atlas, 2003.

MILLER, D. The generic strategy trap. The Journal of Business Strategy, p. 37-41, jan.fev., 1992.

MILLER, A.; DESS, G. G. Assessing Porter's (1980) model in terms of its generalizability, accuracy and simplicity. Journal of Management Studies, v. 30, n. 4, p. 553-585, 1993. 
OLIVEIRA, D. P. R. Estratégia empresarial: uma abordagem empreendedora. 2. ed. São Paulo: Atlas, 1991.

PORTER, M. E. Competitive advantage: creating and sustaining competitive performance. New York: The Free Press, 1985.

Estratégia competitiva: técnicas para análise de indústrias e da concorrência. 9. ed. Rio de Janeiro: Campus, 1995.

SANTOS, J. J. Formação de preços e do lucro empresarial. 2. ed. São Paulo: Atlas, 1988. 196p.

SEBRAE. Serviço de Apoio às Micro e Pequenas Empresas. Critérios de classificação das empresas: MEI-MEEPP. Disponível em: $<$ http://www.sebraesc.com.br/leis/default.asp?vcdtexto=4154>. Acesso em: 25 maio 2012.

SILVA, E. M. Alinhamento das estratégias competitivas com as estratégias de produção: estudo de casos no pólo moveleiro de Votuporanga-SP. 2003. 163 f. Dissertação (Mestrado em Engenharia de Produção) - Escola de Engenharia de São Carlos, Universidade de São Paulo (USP), São Carlos (SP), 2003. Disponível em:

$<$ http://www.teses.usp.br/teses/disponiveis/18/18140/tde-03032005-161204/pt-br.php>.

SOUZA, A.; CLEMENTE, A. Contextos, paradigmas e sistemas de custeio. In: CONGRESSO BRASILEIRO DE GESTÃO ESTRATÉGICA DE CUSTOS, 5., 1998, Fortaleza (CE). Anais... Fortaleza: ABC, 1998. p. 141-156.

SHANK, J.K.; GOVINDARAJAN, V. A revolução dos custos. Rio de Janeiro: Campus, 1997.

TONDOLO, R. R. P. A integração da estratégia competitiva e custos com o processo de desenvolvimento de produtos: um estudo multi-casos. 2010. Dissertação (Mestrado em Administração) - Programa de Pós-Graduação em Administração - PPGA, Universidade de Caxias do Sul (UCS), Caxias do Sul (RS), 2010. Disponível em: $<$ http://tede.ucs.br/tde_arquivos/5/TDE-2010-08-27T132021Z361/Publico/Dissertacao\%20Rosana\%20da\%20Rosa\%20Portella\%20Tondolo.pdf>.

ZUCKERMAN, G. J.; ROMOCKI, T.; CHEN, Y. S. Al. Examination of U.S-based japanese subsidiaries: evidence of the transfer of the Japanese strategic cost management.

International Journal of Accounting, v. 32, n. 4, p. 417-440, 1997. 